\title{
Genetic Analysis of Resistance to Multiple Isolates of Phytophthora capsici and Linkage to Horticultural Traits in Bell Pepper
}

\author{
Jareerat Chunthawodtiporn ${ }^{1}$ \\ Department of Horticulture, Faculty of Agriculture, Kasetsart University, \\ Bangkok, 10900 Thailand
}

\author{
Theresa Hill, Kevin Stoffel, and Allen Van Deynze \\ Seed Biotechnology Center, University of California, Davis, CA 95616
}

Additional index words. QTL analysis, plant breeding, P. capsici, C. annuum, disease resistance

Abstract. Phytophthora capsici is one of the major pathogens found in pepper production, especially in bell pepper. Due to the high level of genetic diversity of the pathogen, bell pepper varieties with broad genetic resistance are essential for disease management. Criollo de Morelos - 334 (CM334), a landrace that has a high level of genetic resistance to $P$. capsici, has been used as the resistant source for $\boldsymbol{P}$. capsici to generate a recombinant inbred line (RIL) population with the susceptible bell pepper cultivar Maor. From the resulting population, quantitative trait locus (QTL) models explaining resistance to each of four isolates of $P$. capsici were derived from QTL regions on three chromosomes using stepwiseqtl in R/qtl. A single region of chromosome 5 contained major QTL for resistance to each of the four isolates. Two isolate-specific QTL conferring resistance to isolates PWB53 and PWB106 were located on chromosomes 10 and 11, respectively. Both isolate-specific QTL had epistatic interactions with a major QTL on chromosome 5. Using the pepper reference genome and gene annotation, candidate genes for $P$. capsici resistance within 1.5-logarithm of odds (LOD) interval were identified. Based on functional annotations derived from Arabidopsis thaliana and solanaceous crop databases, multiple candidate genes related to resistance $(R)$ gene complexes or to plant immune system were found under the QTL on all three chromosomes. A comparison of the locations of resistance QTL and previously identified horticultural QTL using the same population revealed tight linkage between resistance to $P$. capsici and a stem pubescence QTL o chromosome 10. Both candidate genes for $\boldsymbol{P}$. capsici resistance and the linkages between resistance and horticultural traits could be applied for selection to broad resistance to $P$. capsici in bell pepper-breeding programs.

Phytophthora blight, caused by P. capsici, is one of the most economically destructive diseases affecting pepper production in many areas in the United States and other countries around the world (Barksdale et al., 1984; Hausbeck and Lamour, 2004). P. capsici has high genetic diversity in the field because this pathogen is polycyclic and can undergo both sexual reproduction, with different mating types, and asexual reproduction (Erwin and Ribeiro, 1996; Walker and Bosland, 1999).

\footnotetext{
Received for publication 20 July 2018. Accepted for publication 10 Apr. 2019.

We thank the Higher Educational Strategic Scholarships for Frontier Research Network from the Commission on Higher Education, Royal Thai Government for J. Chunthawodtiporn's scholarship; the Jastro Award from the Horticultural and Agronomy Graduate Group, Department of Plant Sciences, University of California-Davis for funding this project; Xiang-yang Zheng, Magnum Seed, Inc., and William Z. Rehrig for inoculation methodology; and Roger T. Chetelat and Robert Gilbertson, University of California, Davis, for critiquing and editing the manuscript.

${ }^{1}$ Corresponding author. E-mail: jareerat.c@ku.th.
}

and Palloix, 1996; Minamiyama et al., 2007; Ogundiwin et al., 2005; Quirin et al., 2005; Rehrig et al., 2014; Sugita et al., 2006; Thabuis et al., 2003; Truong et al., 2012). However, few studies have used multiple isolates to test the resistance to $P$. capsici in their pepper populations. Multiple-isolate resistance to $P$. capsici is necessary for a successful pepper breeding program because of the rapid genetic evolution and diversity of the pathogen (Candole et al., 2010; Glosier et al., 2008; Monroy-Barbosa and Bosland, 2008; Oelke et al., 2003).

Not only is level of resistance important for pepper-breeding programs, other horticultural traits, especially fruit traits, are also essential. Even though CM334 contains genetic resistance for several pathogens including Phytophthora sp., root-knot nematodes, and several types of viruses (Dogimont et al., 1996; Guerrero-Moreno and Laborde, 1980; Kim et al., 2011; Pegard et al., 2005), it has many undesirable characteristics, such as high pungency, anthocyanin, small fruits and leaves, and pubescent stems and leaves (Chunthawodtiporn et al., 2018). In addition, there have not been any studies that examine the combined genetics of horticultural, fruit quality, and the resistance to $P$. capsici traits derived from landraces, e.g., CM334. Thus, this study aimed to determine the genetic basis of broad genetic resistance to $P$. capsici in bell pepper via QTL mapping and candidate gene identification, as well as the relationship between resistance and important horticultural traits for bell pepper breeding.

\section{Materials and Methods}

\section{Plant materials and genetic map}

One hundred twenty RILs and the genetic map used in Chunthawodtiporn et al. (2018) were used for Phytophthora virulence assays and quantitative trait analyzes for resistance to $P$. capsici.

Several methods have been employed to control this disease, including site preparation, irrigation management, crop rotation, use of chemicals or biorational products, and combining different methods together (Bi et al., 2012; Cimen et al., 2009; Hausbeck and Lamour, 2004; Ji et al., 2012; Ristaino and Johnston, 1999; Sanogo and Ji, 2012). However, the use of resistant varieties is the most efficient and environmentally friendly method to manage this disease.

Since the discovery of Phytophthora blight disease in 1922, there have been several studies about the resistance of $P$. capsici in pepper (Leonian, 1922). Many pepper accessions have been reported to possess resistance to $P$. capsici, especially Capsicum annuum landrace 'CM334' (Guerrero-Moreno and Laborde, 1980). Several theories for the genetic basis of this disease resistance have been proposed. For example, early studies suggested simple genetic resistance involving one or a few genes (Ortega et al., 1991; Reifschneider et al., 1992; Walker and Bosland, 1999), whereas subsequent studies have implicated a role for multiple-gene QTL (Kim et al., 2008; Lefebvre

\section{$P$. capsici isolates and virulence assays}

Four of the most virulent isolates of $P$. capsici screened by Rehrig et al., (2014), ISO7, PWB53, PWB106, and PWB128, were used for the virulence assays. $P$. capsici cultures were maintained on V8-agar medium (Ribeiro, 1978). All plants were grown in a greenhouse at UC Davis, CA. The experiments were set up as a randomized complete block design with three replicates per inbred line. Each replicate consisted of seedlings ranging from two to six plants. Seedlings were inoculated at the two- to four-leaf stage (2-3 weeks after planting). Each experiment included CM334, Maor, and Paladin, a hybrid with intermediate resistance, to control the consistency of ratings. The inoculation procedure was modified from Bosland and Lindsey (1991). Each isolate was inoculated individually and freshly cultured on V8-agar for 4 to $5 \mathrm{~d}$. Agar plugs with mycelial growth were excised and placed in a sterile petri dish with sterile distilled water. Cultures were incubated at $25^{\circ} \mathrm{C}$ and 24-h light for $48 \mathrm{~h}$. After $48 \mathrm{~h}$, 
cultures were incubated at $4{ }^{\circ} \mathrm{C}$ for $45 \mathrm{~min}$ followed by room temperature for another 45 min. After incubation, zoospores were counted with a hemocytometer under a light microscope and the concentration was adjusted to 2000 zoospores per milliliter. Five milliliters per plant of zoospore inoculum were delivered to the roots of each plant by submersion of the seedling trays in inoculum. Plants were grown under water saturation conditions by keeping the seedling trays immersed in the water for the duration of the experiment.

Plants were first evaluated for disease severity on a 0 to 5 scale from healthy to dead plant. (Fig. 1) when the susceptible control (Maor) showed a disease symptom of three or more, usually 5 to $10 \mathrm{~d}$ after inoculation based on the virulence of each isolate. Subsequently, each plant was observed and data collected every $2 \mathrm{~d}$ to calculate an area under disease progress curve (AUDPC) until the symptom progress was unchanged (Das et al., 1992). The number of days plants were scored depended on the virulence of each isolate. AUDPC was calculated from

$$
\mathrm{AUDPC}=\sum_{i=1}^{n-1} \frac{y_{i}+y_{i+1}}{2} \times\left(t_{i+1}-t_{i}\right)
$$

where $y_{i}$ is score of plants at day $i$ th observation; $t_{i}$ is a number of days at the $i$ th observation; and $n$ is a number of observation.

\section{Data analyses}

Correlations among traits. P. capsici virulence data from greenhouse experiments were used for statistical analyzes in R [ver- sion 3.2.0 (R Development Core Team, 2005)]. Descriptive statistical analyzes and analysis of variance were performed. Virulence data and horticultural data from Chunthawodtiporn et al. (2018) were used to calculate Pearson pairwise correlations among traits.

QTL analyses and Gene Ontology annotation. Resistance QTL were determined based on AUDPC data using the R package qtl, with scantwo and stepwiseqtl functions. Using the stepwiseqtl functions, QTL models with the maximal penalized LOD score and having $5 \%$ or more of phenotypic variation explained were chosen (Broman and Sen, 2009; Chunthawodtiporn et al., 2018; R Development Core Team, 2005). A summary of individual terms in the QTL models were calculated from the makeqtl and fitqtl function. Genomic regions from QTL intervals were identified by the physical position of the closet single-nucleotide polymorphism flanking the intervals on the reference genome. Candidate genes were determined based on the method of Chunthawodtiporn et al. (2018), with their physical or biological functions, that have been reported in databases from Arabidopsis thaliana and solanaceous crops.

\section{Results}

Correlation among traits. To explore relationships among traits, correlations between horticultural traits previously measured for the RIL population and levels of resistance to $P$. capsici were calculated. The traits could be separated into different groups including fruit traits, leaf traits, stem pubescence, anthocyanin accumulation in young fruit, and resistance to $P$. capsici. Generally within their respective groups, fruit traits and leaf traits had positive, significant correlation with each other (Fig. 2). The AUDPC measures of resistance to $P$. capsici were also positively, significantly correlated between all isolates but not correlated with any fruit or leaf traits. Stem pubescence was negatively correlated with all of the leaf traits and the AUDPC of PWB53, but not to AUDPC of the other isolates. Purple stripes from anthocyanin on immature fruit were negatively correlated with susceptibility to all $P$. capsici isolates.

QTL analyses and Gene Ontology annotation. There were three resistance QTL regions identified from the four isolate studied. All QTL had the resistance effect coming from the CM334 alleles. Across all four isolates, resistance QTL were located to on three chromosomes (Table 1, Fig. 3). The major QTL for all isolates was found on chromosome 5, which had the percentages of phenotypic variation explained ranging from $39.0 \%$ to $72.5 \%$.

There were two isolate-specific QTL detected with PWB53 and PWB106 on chromosomes 10 and 11 , respectively. The individual QTL on chromosome 10 for PWB53 explained $42.6 \%$, whereas QTL on chromosome 11 for PWB106 explained $19.2 \%$ of phenotypic variation. In addition, these QTL had epistatic interactions with the major QTL on chromosome 5, accounting for $23.3 \%$ and $11.8 \%$ of the phenotypic variation with PWB53 and PWB106, respectively (Fig. 4).

To understand the resistance mechanism to $P$. capsici, all the resistance QTL were investigated by determining the functions of
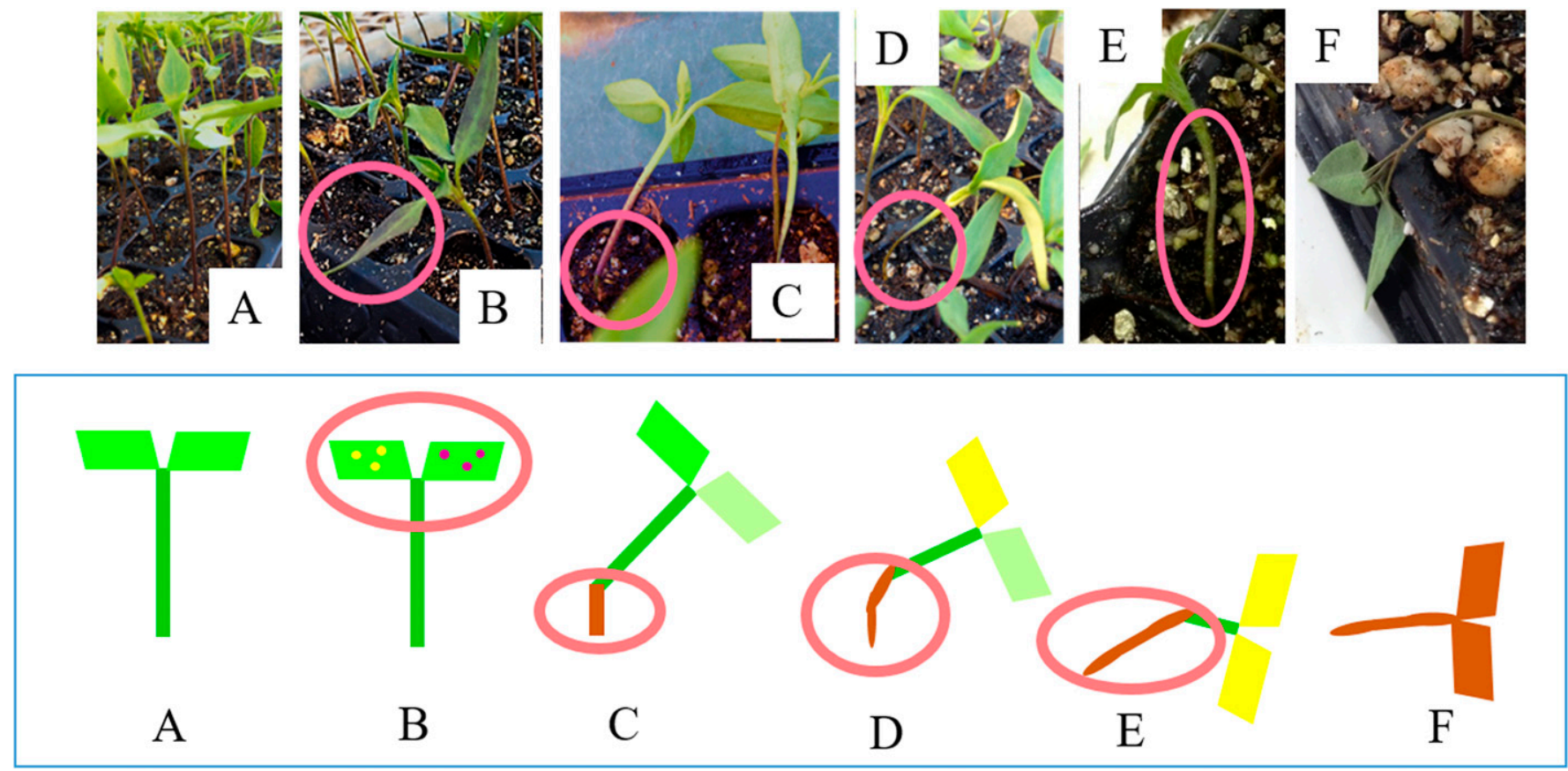

Fig. 1. P. capsici disease rating scale from 0 to $5: 0=$ no symptoms/healthy plant $(\mathbf{A}) ; 1=$ leaf yellowing or curling but no stem discoloration or necrosis $(\mathbf{B}) ; 2=$ minor stem girdling at the base of stem $(\mathbf{C}) ; 3=$ moderate stem necrosis and wilting $(\mathbf{D}) ; 4=$ severe stem girdling and wilting with leaf necrosis $(\mathbf{E}) ; 5=$ dead plant (F). Top pictures show actual inoculated plants with representative diagrams shown at the bottom. 
underlying genes based on their homologs present in the A. thaliana and solanaceous crops' databases. The potential candidate genes for resistance to $P$. capsici are shown in Supplemental Table 1. Candidate genes were placed into different groups, based on their inferred biological functions. The number of candidate genes that were found under QTL from four isolates were 37, 22, and 11

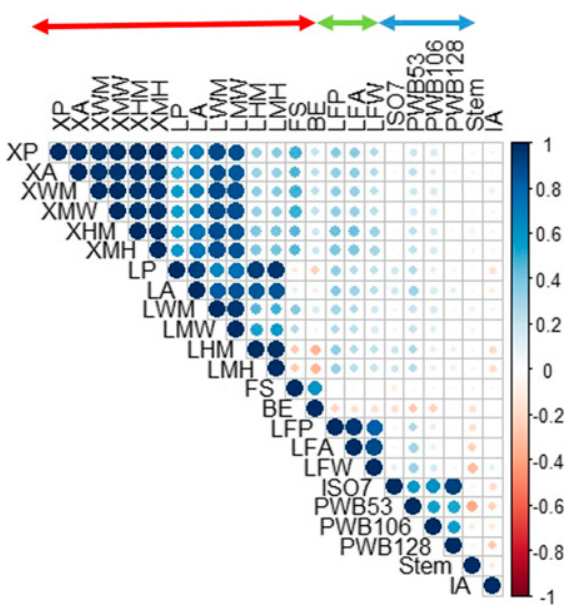

Fig. 2. Twenty-three Pearson correlations among horticultural traits (Chunthawodtiporn, et al., 2018) and $P$. capsici virulence experiments. Fruit traits (red arrow) including XP = transverse perimeter, $\mathrm{XA}=$ transverse area, $\mathrm{XWM}=$ transverse width midheight, $\mathrm{XMW}=$ transverse maximum width, $\mathrm{XHM}=$ transverse height midwidth, $\mathrm{XMH}=$ transverse maximum height, LP $=$ longitudinal perimeter, $\mathrm{LA}=$ longitudinal area, LWM = longitudinal width midheight, LMW = longitudinal maximum width; LHM = longitudinal height midwidth, $\mathrm{LMH}=$ longitudinal maximum height, $\mathrm{FS}=$ fruit shape, $\mathrm{BE}=$ blossom-end shape; leaf traits (green arrow) including LFP = leaf perimeter, LFA = leaf area, LFW = leaf width midheight; $P$. capsici resistance traits (blue arrow) including ISO7 = resistance to $\mathrm{ISO} 7, \mathrm{PWB} 53=$ resistance to PWB53, PWB106 = resistance to PWB106, PWB128 = resistance to $\mathrm{PWB} 128 ;$ Stem $=$ stem pubescence; IA = anthocyanin stripe on young fruits. Blue circle $=$ positive correlation between traits on the row and column; red circle = negative correlation between traits on the row and column. under chromosomes 5, 10, and 11, respectively.

\section{Discussion}

Phytophthora blight from $P$. capsici was discovered and has been studied since 1922 (Lefebvre and Palloix, 1996; Leonian, 1922; Kim et al., 2008; Minamiyama et al., 2007; Ogundiwin et al., 2005; Ortega et al., 1991; Quirin et al., 2005; Rehrig et al., 2014; Reifschneider et al., 1992; Sugita et al., 2006; Thabuis et al., 2003; Truong et al., 2012; Walker and Bosland, 1999). However, the mechanism of disease resistance has been difficult to unravel. In this study, RILs from Chunthawodtiporn et al. (2018) were assayed with multiple $P$. capsici isolates that had been tested previously in other pepper populations (Rehrig et al., 2014) to identify loci conferring resistance to Phytophthora root rot. Use of several isolates of $P$. capsici with different levels of virulence is a key to breeding for broad spectrum resistance. Broad resistance is necessary for this disease because $P$. capsici has been shown to exist as multiple physiological races and two different mating types of sexual spores in a single field, leading to the continual emergence of new races (Oelke et al., 2003; Polach and Webster, 1972; Reifschneider et al., 1992). Use of broad resistant peppers reduces the chance of this pathogen break out in the field.

Resistance loci to P. capsici. Most published QTL analyzes for resistance to $P$. capsici in pepper populations, including this study, have reported a QTL mapped to chromosome 5 even though different resistant sources, pepper populations, and disease assays have been used (Bonnet et al., 2007; Kim et al., 2002, 2008; Mallard et al., 2013; Minamiyama et al., 2007; Ogundiwin et al., 2005; Quirin et al., 2005; Rehrig et al., 2014; Sy et al., 2008; Thabuis et al., 2003; Truong et al., 2012). In a recent study, Mallard et al. (2013) examined different sources of $P$. capsici resistance and conducted a metaanalysis of QTL studies and found three QTL on chromosome 5: Pc5.1, Pc5.2, and Pc5.3, with Pc5.1 representing the major QTL conferring resistance to multiple isolates. However, the only one locus at $14.0 \mathrm{cM}$ on chromosome 5 was detected in the current study, possibly due to the limited usable number of single-nucleotide polymorphism markers from genotype-by-sequencing and the fact that only CM334 was used as the source of $P$. capsici resistance. Thus, the major QTL in this study may correspond to Pc5.1, based on its broad genetic resistance across multiple isolates.

Isolate-specific or race-specific resistance is consistent with a gene-for-gene theory in the relationship between plant host and pathogen when each gene in the host corresponds to an effector gene in the pathogen that conditions pathogenicity (Flor, 1971). These interactions between $P$. capsici and $C$. annuum for Phytophthora rot was confirmed with an $\mathrm{F}_{2}$ population to locate the resistance loci for different $P$. capsici isolates (Monroy-Barbosa and Bosland, 2008). This was in agreement with subsequent studies that used multiple isolate assays as Truong et al. (2012) and this study. We found two isolate-specific QTL, on chromosomes 10 and 11, associated with two isolates of P. capsici, PWB53 and PWB106, respectively (Table 1). Recently, an isolatespecific single, dominant gene conferring resistance to $P$. capsici was identified using bulk segregant analysis in a backcross population from CM334 as a resistant source (Xu et al., 2016). This locus was located at the end of long arm of chromosome 10, in a similar location as the QTL from PWB53. However, this backcross population did not detect the major QTL on chromosome 5 found in other studies (Kim et al., 2008; Mallard et al., 2013; Ogundiwin et al., 2005; Quirin et al., 2005; Rehrig et al., 2014; Thabuis et al., 2003). Our isolate-specific QTL was consistent with previous studies that found these two QTL from several resistant sources (Kim et al., 2008; Ogundiwin et al., 2005; Thabuis et al., 2003; Truong et al., 2012). In addition, our study also found the epistatic interactions between two $P$. capsici resistance loci (Table 1, Fig. 4) that have been reported in the previous studies (Bartual et al., 1991; Lefebvre and Palloix, 1996; Ogundiwin et al., 2005; Thabuis et al., 2003). The interaction between the resistance loci from QTL on chromosomes 5 and 10 that has been published by Thabuis et al. (2003) was consistent with our result for isolate

Table 1. QTL for P. capsici resistance using stepwiseqtl from R/qtl in RIL population for a cross between Maor and CM334.

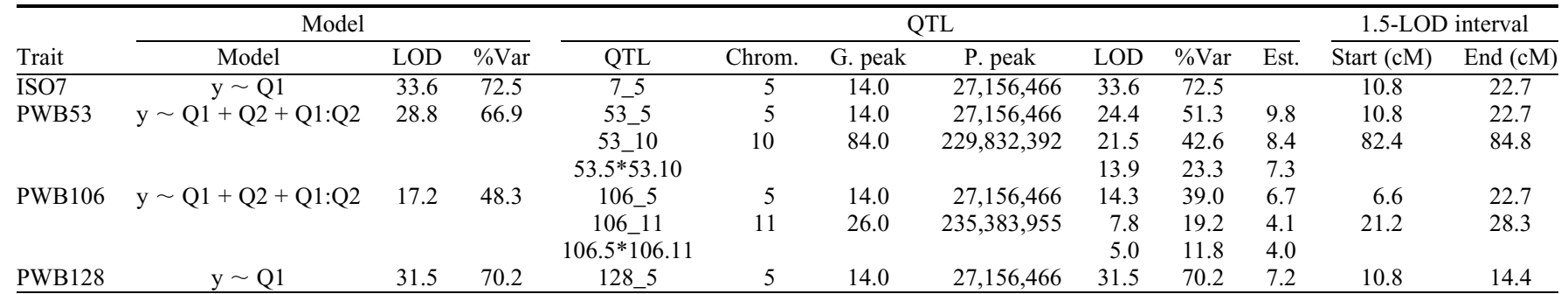

$\mathrm{QTL}=$ quantitative trait locus; 1.5 -LOD $=1.5$-LOD interval of the QTL; LOD $=$ logarithm of odds; \%Var $=$ the percentage of phenotypic variance explained by QTLs; Chrom. = chromosome; G. peak = genetic position at the peak of QTL (cM); P. peak = physical position at the peak of QTL; Est. = estimate effect of QTL. The positive value of estimated effect (susceptibility) came from Maor alleles; Start = starting position for 1.5-LOD interval; End = ending position for 1.5-LOD interval; Q1, Q2 = each QTL on a trait such as PWB53 has 2 QTL = Q1 and Q2; Q1:Q2 = epistatic interaction between Q1 and Q2. 


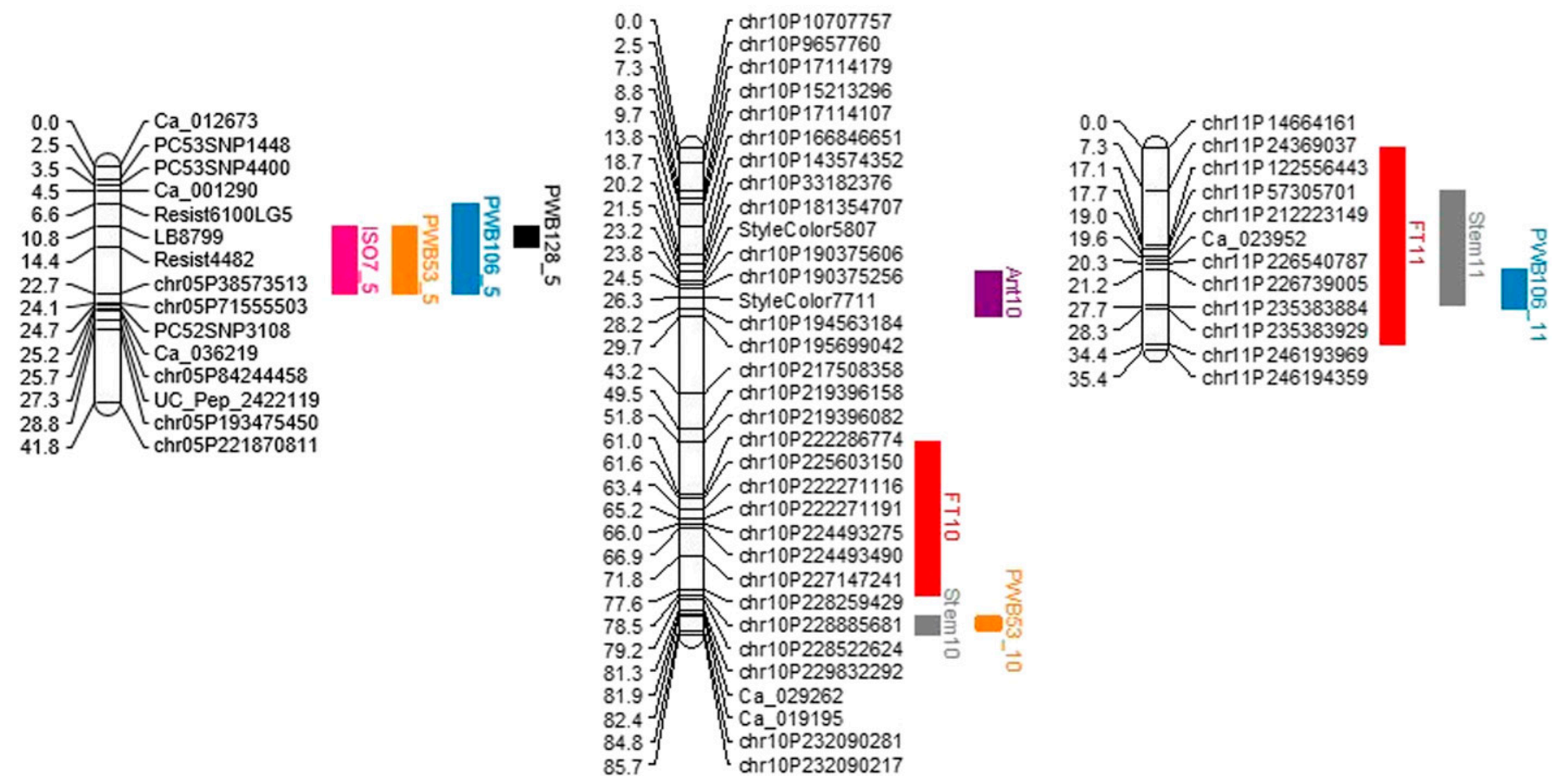

Fig. 3. Quantitative trait locus (QTL) map of P. capsici resistance and horticultural traits (Chunthawodtiporn et al., 2018) on chromosomes 5, 10, and 11. Genetic distance $(\mathrm{cM})$ is on the left side of chromosomes and markers are on the right side. QTL are presented as the bars on the right of chromosomes. The length of each bar shows 1.5-logarithm of odds interval of QTL. For resistance to P. capsici QTL, ISO7 QTL is represented as a pink bar; PWB53 QTL are orange bars; PWB106 QTL are blue bars; and PWB128 QTL is a black bar. For horticultural traits, fruit QTL are illustrated as red bars; stem pubescence QTL are gray bars; and anthocyanin stripes in young fruit QTL as a purple bar (Chunthawodtiporn et al., 2018)

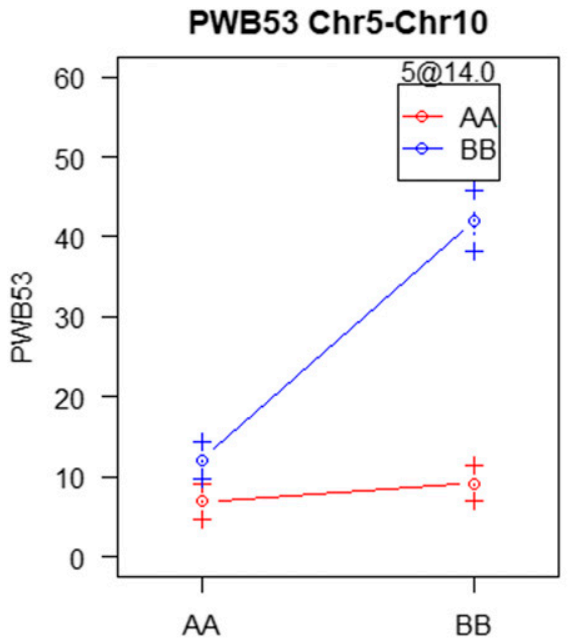

10@84.0
PWB106 between Chr5-Chr11

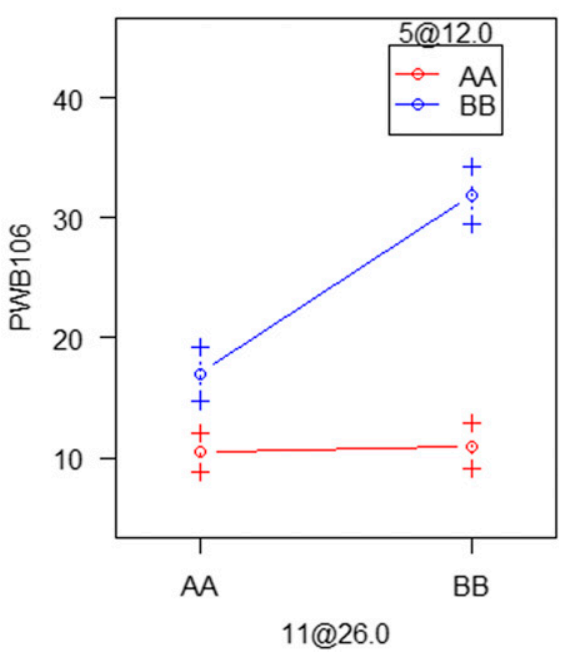

Fig. 4. Effect plots that exhibit the epistatic interactions between two quantitative trait locus (QTL) for each P. capsici isolate. On the left graph, PWB53 had the additive interaction between QTL on chromosome 5 at $14.0 \mathrm{cM}$ and QTL on chromosome 10 at $84.0 \mathrm{cM}$. On the right graph, PWB106 had the additive interaction between QTL on chromosome 5 at $12.0 \mathrm{cM}$ and QTL on chromosome 11 at $26.0 \mathrm{cM}$. The AA allele came from the resistant parent ' $\mathrm{CM} 334$ ', and BB allele was from susceptible bell pepper parent 'Maor'. Scale on y-axis shows areas under the disease progress curve data which represent the level of susceptibility. The positions next to AA and BB alleles are the positions and chromosome numbers of the peaks of QTL.

PWB53. Moreover, our study were able to detect an interaction with isolate PWB106 between resistance loci on chromosomes 5 and 11. For both interactions, we were able to evaluate additive-by-additive epistatic inter- actions but could not calculate dominant effect of the interactions due to the type of plant material (RIL).

Candidate genes for $\mathrm{P}$. capsici under QTL. Potential candidate genes associated with QTL for resistance to $P$. capsici were identified by comparing protein sequences and annotations with known disease resistance genes from $A$. thaliana and other crops in Solanaceous databases (Chunthawodtiporn et al., 2018). Several R-gene clusters were found under all QTL (Supplemental Table 1). $\mathrm{R}$ proteins are classified into several subclasses that are defined by the presence of specific protein domains including the leucine rich repeat domain, nucleotide-binding site domain, and an amino acid terminal (Nterminal) domain with homology to a tollinterleukin-1-receptor domain (Lawrence et al., 1995). $\mathrm{R}$ proteins act as receptors in pathogen recognition and signaling for disease resistance mechanisms (Ellis et al., 2000; Jones and Dangl, 2006; Meyers et al., 2002; Tan and $\mathrm{Wu}, 2012$ ). One of the several resistance genes under the major QTL on chromosome 5 were R2 late blight resistance genes, which were CA05g05390, CA05g05440, and CA05g05720 (Supplemental Table 1). These genes belonged to NB-ARC-domain containing disease resistance gene encoding one of the domains of resistance gene in potato (Ballvora et al., 2002; Park et al., 2005).

Several putative $\mathrm{R}$ proteins including plant cell receptor, receptor-like protein, and receptor-like protein kinase genes are annotated under the QTL regions. Some annotated genes have been studied, for example, pathogen-associated molecular pattern recognition receptors such as the 
mitogen-activated protein kinase under chromosome 11 (Hein et al., 2009). Not only plant cell receptors were classified as the candidate genes for plant disease resistance, physical barriers such as the plant cell wall were considered. Cell wall strength is a defense mechanism mediated by lignification from enzyme cell wall peroxidase (Bechinger et al., 1999). CanPO2 and CanPOD, two peroxidase proteins, have been studied in pepper and found to be involved in upregulating $P$. capsici resistance after treatments with biotic and abiotic stresses (Choi and Hwang, 2012; Wang et al., 2013). We postulate that the resistance against multiple isolates conferred by the chromosome 5 QTL in this experiment and the many publications could be due to several active genes clustered in this region. For example, CaDMR1, although not segregating in our population, was proposed as a candidate gene under the QTL on chromosome 5 (Rehrig et al., 2014). Fine mapping in several populations, functional analyzes, complementation, and allelic tests are required to determine which genes confer resistance to $P$. capsici under this QTL and others identified. Combined evidence suggests that a different combination of alleles and genes may be responsible for broad genetic resistance to $P$. capsici in the gene cluster found under the major QTL on chromosome 5 in different genetic backgrounds.

Linkages of QTL between $P C$ resistance and horticultural traits. There have been several studies investigating sources of resistance to $P$. capsici in pepper. However, not many studies have reported the relationship between undesirable traits, which are common traits in resistant sources such as CM334, and the desirable resistance traits for plant breeding programs. In this study, the major resistance QTL for all isolates was located on chromosome 5, whereas isolatespecific QTL were located on chromosomes 10 and 11 (Fig. 3). Alleles for horticultural trait QTL from Chunthawodtiporn et al. (2018) were linked in repulsion to QTL for resistance to $P$. capsici on chromosomes 10 and 11 (Fig. 3). On chromosome 10, the QTL for PWB53 resistance was located at the same chromosome as the QTL for anthocyanin accumulation in young fruit and was linked $(23.0 \mathrm{cM})$ to a minor QTL for fruit size. Moreover, it was tightly linked $(1.6 \mathrm{cM})$ to QTL for stem pubescence. This result also was observed by Kim et al. (2010). They reported the fine mapping of the pepper trichome locus1 that controlled trichome formation in C. annuum 'CM334' and was tightly linked to resistance to pepper mottle virus (PepMoV). On chromosome 11, the QTL for PWB106 resistance was linked in repulsion to two minor horticultural QTL, fruit size and stem pubescence QTL (5.7 and $7.0 \mathrm{cM}$, respectively, Chunthawodtiporn et al., 2018).

In conclusion, this study supports the multiple gene resistance for $P$. capsici in pepper with the major QTL located on chromosome 5 and identified isolatespecific resistance loci having epistatic in- teractions with the major QTL. Comparisons with horticultural QTL identified in the same population showed linkage between resistance and horticultural traits in repulsion, i.e., unfavorable for commercial pepper types. Leveraging the genotype-by-sequencing method and the availability of a pepper reference genome with annotated gene models, we were able to identify a number of candidate genes based on the physical positions of QTL markers and predicted protein functions of the underlying genes. Several genes encoding $\mathrm{R}$ proteins were found.

\section{Literature Cited}

Ashrafi, H., T.A. Hill, K. Stoffel, A. Kozik, J. Yao, S.R. Chin-Wo, and A. Van Deynze. 2012. De novo assembly of the pepper transcriptome (Capsicum annuum): A benchmark for in silico discovery of SNPs, SSRs and candidate genes. BMC Genomics 13:571.

Ballvora, A., M.R. Ercolano, J. Weiß, K. Meksem, C.A. Bormann, P. Oberhagemann, F. Salamini, and C. Gebhardt. 2002. The R1 gene for potato resistance to late blight (Phytophthora infestans) belongs to the leucine zipper/NBS/LRR class of plant resistance genes. Plant J. 30(3):361-371.

Barksdale, T.H., G.C. Papavizas, and S.A. Johnston. 1984. Resistance to foliar blight and crown rot of pepper caused by Phytophthora capsici. Plant Dis. 68(6):506-509.

Bartual, R., E.A. Carbonell, J.I. Marsal, J.C. Tello, and T. Campos. 1991. Gene action in the resistance of peppers (Capsicum annuum) to Phytophthora stem blight (Phytophthora capsici L.). Euphytica 54(2):195-200.

Bechinger, C., K.F. Giebel, M. Schnell, P. Leiderer, H.B. Deising, and M. Bastmeyer. 1999. Optical measurements of invasive forces exerted by appressoria of a plant pathogenic fungus. Science 285(5435): 1896-1899.

Bi, Y., H. Jiang, M.K. Hausbeck, and J.J. Hao. 2012. Inhibitory effects of essential oils for controlling Phytophthora capsici. Plant Dis. 96(6):797-803.

Bonnet, J., S. Danan, C. Boudet, L. Barchi, A.M Sage-Palloix, B. Caromel, A. Palloix, and V. Lefebvre. 2007. Are the polygenic architectures of resistance to Phytophthora capsici and $P$. parasitica independent in pepper? Theor. Appl. Genet. 115(2):253-264.

Bosland, P.W. and D.L. Lindsey. 1991. A seedling screen for Phytophthora root rot of pepper, Capsicum annuum. Plant Dis. 75(10):10481050.

Broman, K.W. and S. Sen. 2009. A guide to QTL mapping with R/qtl. Springer, New York.

Candole, B.L., P.J. Conner, and P. Ji. 2010. Screening Capsicum annuum accessions for resistance to six isolates of Phytophthora capsici. HortScience 45(2):254-259.

Choi, H.W. and B.K. Hwang. 2012. The pepper extracellular peroxidase $\mathrm{CaPO} 2$ is required for salt, drought and oxidative stress tolerance as well as resistance to fungal pathogens. Planta 235(6):1369-1382.

Chunthawodtiporn, J., T. Hill, K. Stoffel, and A. Van Deynze. 2018. Quantitative trait loci controlling fruit size and other horticultural traits in bell pepper (Capsicum anпииm). Plant Genome 11(1).

Cimen, I., V. Pirinc, A. Sagir, C. Akpinar, and S. Guzel. 2009. Effects of solarization and vesicular arbuscular mycorrhizal fungus (VAM) on
Phytophthora blight (Phytophthora capsici Leonian) and yield in pepper. Afr. J. Biotechnol. 8(19):4884.

Das, M.K., S. Rajaram, C.C. Mundt, and W.E. Kronstad. 1992. Inheritance of slow-rusting resistance to leaf rust in wheat. Crop Sci. 32(6): 1452-1456.

Dogimont, C., A. Palloix, A.M. Daubze, G. Marchoux, K.G. Selassie, and E. Pochard. 1996. Genetic analysis of broad spectrum resistance to potyviruses using doubled haploid lines of pepper (Capsicum annuum L.). Euphytica 88(3):231239.

Ellis, J., P. Dodds, and T. Pryor. 2000. Structure, function and evolution of plant disease resistance genes. Curr. Opin. Plant Biol. 3(4):278284.

Erwin, D.C. and O.K. Ribeiro. 1996. Phytophthora diseases worldwide. American Phytopathological Society (APS Press), St. Paul, MN.

Flor, H.H. 1971. Current status of the genefor-gene concept. Annu. Rev. Phytopathol. 9(1):275-296.

Glosier, B.R., E.A. Ogundiwin, G.S. Sidhu, D.R. Sischo, and J.P. Prince. 2008. A differential series of pepper (Capsicum annuum) lines delineates fourteen physiological races of Phytophthora capsici. Euphytica 162(1):23-30.

Guerrero-Moreno, A. and J.A. Laborde. 1980 Current status of pepper breeding for resistance to Phytophthora capsici in Mexico. In: Current status of pepper breeding for resistance to Phytophthora capsici in Mexico, Synopses of the IVth Eucarpia Meeting on Capsicum Wageningen, The Netherlands. p. 52-56.

Hausbeck, M.K. and K.H. Lamour. 2004. Phytophthora capsici on vegetable crops: Research progress and management challenges. Plant Dis. 88(12):1292-1303.

Hein, I., E.M. Gilroy, M.R. Armstrong, and P.R. Birch. 2009. The zig-zag-zig in oomycete-plant interactions. Mol. Plant Pathol. 10(4):547562.

Ji, P., D. Koné, J. Yin, K.L. Jackson, and A.S. Csinos. 2012. Soil amendments with Brassica cover crops for management of Phytophthora blight on squash. Pest Manag. Sci. 68(4):639644 .

Jones, J.D. and J.L. Dangl. 2006. The plant immune system. Nature 444(7117):323.

Kim, K.T., H.S. Choi, Y. Chae, D.-G. Oh, and B.D. Kim. 2002. August. Mapping QTL associated with Phytophthora root rot resistance in chili (Capsicum annuum). In XXVI International Horticultural Congress: Advances in Vegetable Breeding 637. Toronto, Canada. p. 251-255.

Kim, H.J., J.H. Han, S. Kim, H.R. Lee, J.S. Shin, J.H. Kim, J. Cho, Y.H. Kim, H.J. Lee, B.D. Kim, and D. Choi. 2011. Trichome density of main stem is tightly linked to PepMoV resistance in chili pepper (Capsicum annuит L.). Theor. Appl. Genet. 122(6):1051-1058.

Kim, H.J., J.H. Han, J.K. Kwon, M. Park, B.D. Kim, and D. Choi. 2010. Fine mapping of pepper trichome locus 1 controlling trichome formation in Capsicum annuum L. CM334. Theor. Appl. Genet. 120(6):1099-1106.

Kim, H.J., S.H. Nahm, H.R. Lee, G.B. Yoon, K.T. Kim, B.C. Kang, D. Choi, O.Y. Kweon, M.C. Cho, J.K. Kwon, and J.H. Han. 2008. BACderived markers converted from RFLP linked to Phytophthora capsici resistance in pepper (Capsicum annuum L.). Theor. Appl. Genet. 118(1):15

Kim, S., M. Park, S.I. Yeom, Y.M. Kim, J.M. Lee, H.A. Lee, E. Seo, J. Choi, K. Cheong, K.T. Kim, and K. Jung. 2014. Genome sequence of the hot pepper provides insights into the 
evolution of pungency in Capsicum species. Nat. Genet. 46(3):270.

Lawrence, G.J., E.J. Finnegan, M.A. Ayliffe, and J.G. Ellis. 1995. The L6 gene for flax rust resistance is related to the Arabidopsis bacterial resistance gene RPS2 and the tobacco viral resistance gene N. Plant Cell 7(8):1195-1206.

Lefebvre, V. and A. Palloix. 1996. Both epistatic and additive effects of QTLs are involved in polygenic induced resistance to disease: A case study, the interaction pepper - Phytophthora capsici Leonian. Theor. Appl. Genet. 93(4):503-511.

Leonian, L.H. 1922. Stem and fruit blight of peppers caused by Phytophthora capsici sp. nov. Phytopathology 12(9):401-408.

Mallard, S., M. Cantet, A. Massire, A. Bachellez, S. Ewert, and V. Lefebvre. 2013. A key QTL cluster is conserved among accessions and exhibits broad-spectrum resistance to Phytophthora capsici: A valuable locus for pepper breeding. Mol. Breed. 32(2):349-364.

Meyers, B.C., M. Morgante, and R.W. Michelmore. 2002. TIR-X and TIR-NBS proteins: Two new families related to disease resistance TIR-NBS-LRR proteins encoded in Arabidopsis and other plant genomes. Plant J. 32(1):7792.

Minamiyama, Y., M. Tsuro, T. Kubo, and M. Hirai. 2007. QTL analysis for resistance to Phytophthora capsici in pepper using a high density SSR-based map. Breed. Sci. 57(2):129-134.

Monroy-Barbosa, A. and P.W. Bosland. 2008. Genetic analysis of Phytophthora root rot race-specific resistance in Chile pepper. J. Amer. Soc. Hort. Sci. 133:825-829.

Park, T.H., V.G.A.A. Vleeshouwers, D.J. Huigen, E.A.G. van der Vossen, H.J. van Eck, and R.G.F. Visser. 2005. Characterization and high-resolution mapping of a late blight resistance locus similar to R2 in potato. Theor. Appl. Genet. 111:591-597.

Pegard, A., G. Brizzard, A. Fazari, O. Soucaze, P. Abad, and C. Djian-Caporalino. 2005. Histological characterization of resistance to different root-knot nematode species related to phenolics accumulation in Capsicum annuum. Phytopathology 95(2):158-165.

Polach, F.J. and R.K. Webster. 1972. Identification of strains and inheritance of pathogenicity in Phytophthora capsici. Phytopathology 62(1):20-26.
Oelke, L.M., P.W. Bosland, and R. Steiner. 2003. Differentiation of race specific resistance to Phytophthora root rot and foliar blight in Capsicum annuum. J. Amer. Soc. Hort. Sci. 128:213-218.

Ogundiwin, E.A., T.F. Berke, M. Massoudi, L.L. Black, G. Huestis, D. Choi, S. Lee, and J.P. Prince. 2005. Construction of 2 intraspecific linkage maps and identification of resistance QTLs for Phytophthora capsici root-rot and foliar-blight diseases of pepper (Capsicum annuиm L.). Genome 48(4):698-711.

Ortega, R.G., C.P. Español, and J.C. Zueco. 1991. Genetics of resistance to Phytophthora capsici in the pepper line 'SCM-334'. Plant Breed. 107(1):50-55.

Quirin, E.A., E.A. Ogundiwin, J.P. Prince, M. Mazourek, M.O. Briggs, T.S. Chlanda, K.T. Kim, M. Falise, B.C. Kang, and M.M. Jahn. 2005. Development of sequence characterized amplified region (SCAR) primers for the detection of Phyto. 5.2, a major QTL for resistance to Phytophthora capsici Leon. in pepper. Theor. Appl. Genet. 110(4):605-612.

R Development Core Team. 2005. R: A language and environment for statistical computing, reference index version 2.2.1. R Foundation, Vienna, Austria.

Rehrig, W.Z., H. Ashrafi, T. Hill, J. Prince, and A. Van Deynze. 2014. CaDMRI cosegregates with QTL Pc5. 1 for resistance to Phytophthora capsici in pepper (Capsicum annuum). Plant Genome 7(2).

Reifschneider, F.J.B., L.S. Boiteux, P.T. Della Vecchia, J.M. Poulos, and N. Kuroda. 1992. Inheritance of adult-plant resistance to Phytophthora capsici in pepper. Euphytica 62(1):45-49.

Ribeiro, O.K. 1978. A source book of the genus Phytophthora. J. Cramer, Braunschweig, Germany.

Ristaino, J.B. and S.A. Johnston. 1999. Ecologically based approaches to management of Phytophthora blight on bell pepper. Plant Dis. 83(12):1080-1089.

Sanogo, S. and P. Ji. 2012. Integrated management of Phytophthora capsici on solanaceous and cucurbitaceous crops: Current status, gaps in knowledge and research needs. Can. J. Plant Pathol. 34(4):479-492.
Sugita, T., K. Yamaguchi, T. Kinoshita, K. Yuji, Y. Sugimura, R. Nagata, S. Kawasaki, and A. Todoroki. 2006. QTL analysis for resistance to Phytophthora blight (Phytophthora capsici Leon.) using an intraspecific doubled-haploid population of Capsicum annuum. Breed. Sci. 56(2):137-145.

Sy, O., R. Steiner, and P.W. Bosland. 2008. Recombinant inbred line differential identifies race-specific resistance to Phytophthora root rot in Capsicum annuum. Phytopathology 98(8):867-870.

Tan, S. and S. Wu. 2012. Genome wide analysis of nucleotide-binding site disease resistance genes in Brachypodium distachyon. Comp. Funct. Genomics. 2012:418208.

Thabuis, A., A. Palloix, S. Pflieger, A.M. Daubeze, C. Caranta, and V. Lefebvre. 2003. Comparative mapping of Phytophthora resistance loci in pepper germplasm: Evidence for conserved resistance loci across Solanaceae and for a large genetic diversity. Theor. Appl. Genet. 106(8):1473-1485.

Truong, H.T.H., K.T. Kim, D.W. Kim, S. Kim, Y. Chae, J.H. Park, D.G. Oh, and M.C. Cho. 2012. Identification of isolate-specific resistance QTLs to Phytophthora root rot using an intraspecific recombinant inbred line population of pepper (Capsicum annuum). Plant Pathol. 61(1):48-56.

Walker, S.J. and P.W. Bosland. 1999. Inheritance of Phytophthora root rot and foliar blight resistance in pepper. J. Amer. Soc. Hort. Sci. 124:14-18.

Wang, J.E., K.K. Liu, D.W. Li, Y.L. Zhang, Q. Zhao, Y.M. He, and Z.H. Gong. 2013. A novel peroxidase CanPOD gene of pepper is involved in defense responses to Phytophtora capsici infection as well as abiotic stress tolerance. Intl. J. Mol. Sci. 14(2):3158-3177.

Xu, X., J. Chao, X. Cheng, R. Wang, B. Sun, H. Wang, S. Luo, X. Xu, T. Wu, and Y. Li. 2016. Mapping of a novel race specific resistance gene to Phytophthora root rot of pepper (Capsicum annuum) using bulked segregant analysis combined with specific length amplified fragment sequencing strategy. PLoS One 11(3):E0151401. 
Supplemental Table 1. Susceptibility data for $P$. capsici. Area under disease progress curve (AUDPC) data determining susceptibility of each RIL for each $P$. capsici isolate AUDPC data of each isolate.

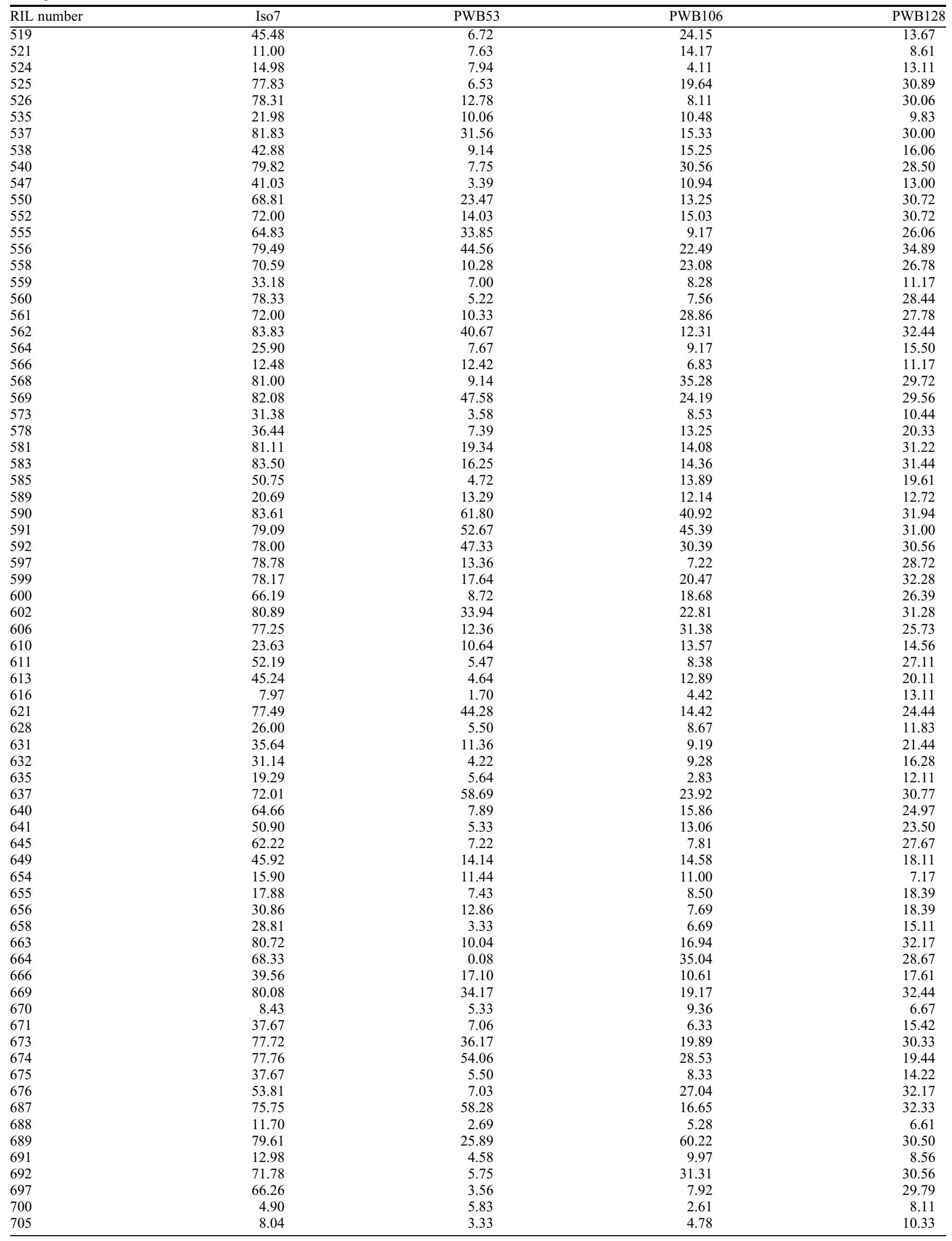

(Continued on next page) 
Supplemental Table 1. (Continued) Susceptibility data for $P$. capsici. Area under disease progress curve (AUDPC) data determining susceptibility of each RIL for each $P$. capsici isolate AUDPC data of each isolate.

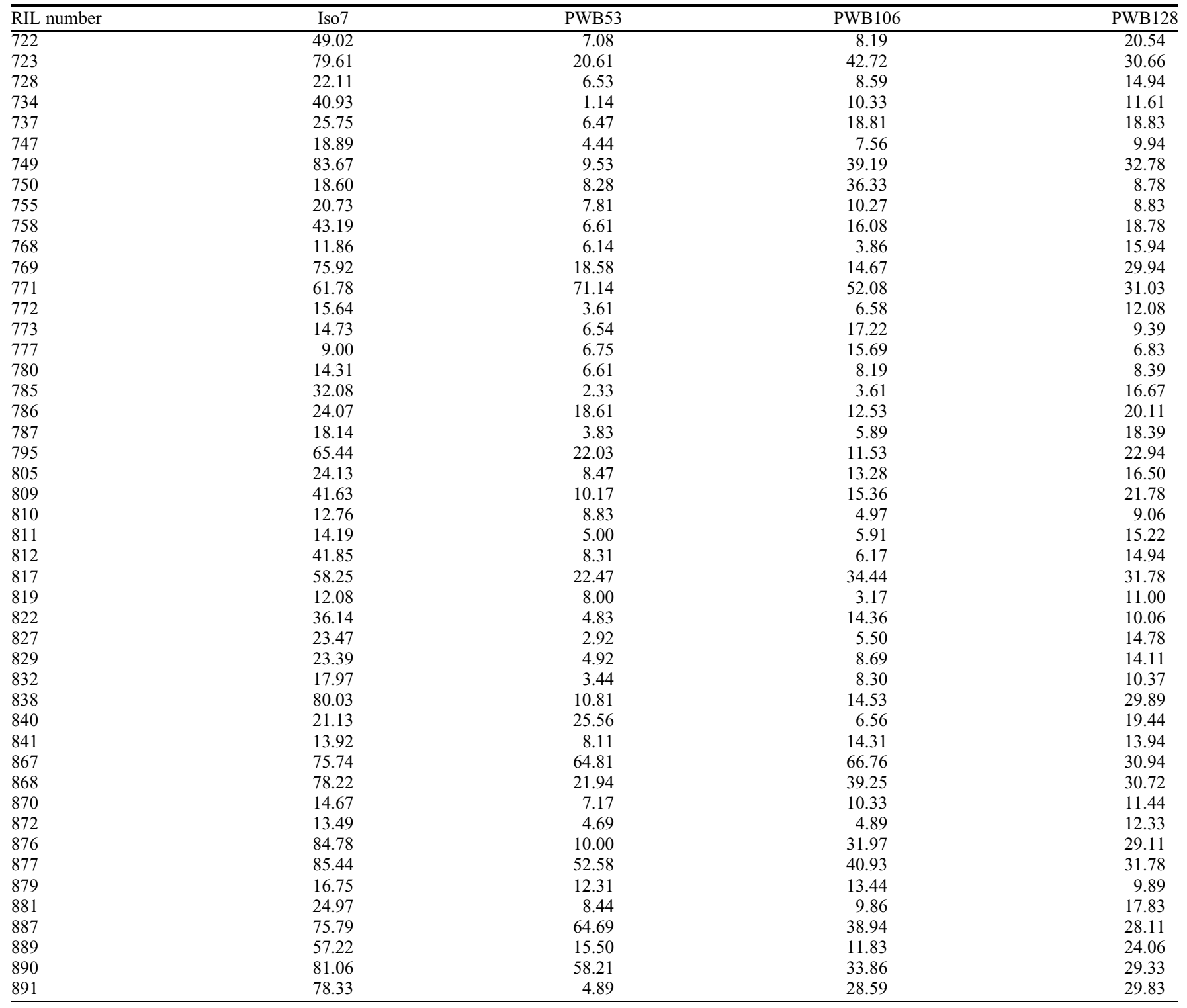

